\title{
Characteristics, Cardiovascular Comorbidity and Medicines Management in Patients with Type 2 Diabetes and CKD: Results of the IRIDIEM Study
}

\author{
P.E. Stevens ${ }^{a} \quad$ G. Schernthaner ${ }^{b} \quad$ S. Raptis ${ }^{c} \quad$ C. Wanner ${ }^{d} \quad$ A. Scherhag ${ }^{e}$ \\ N. Lameire ${ }^{f}$ \\ a Department of Renal Medicine, Kent and Canterbury Hospital, Canterbury, UK; ${ }^{b}$ Department of Diabetology, \\ Krankenanstalt Rudolfstiftung, Vienna, Austria; ' 2 nd Department of Internal Medicine, Research Institute \\ and Diabetes Centre, Athens University Medical School, University Hospital 'Attikon', Athens, Greece; \\ ${ }^{d}$ Department of Medicine, Division of Nephrology, University Hospital, University of Würzburg, Würzburg,

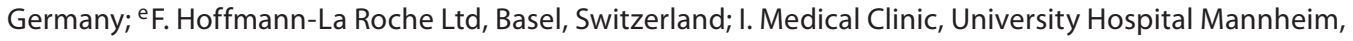 \\ University of Heidelberg, Heidelberg, Germany; ${ }^{f}$ Renal Division, Ghent University Hospital, Ghent, Belgium
}

\section{Key Words}

Chronic kidney disease $\cdot$ Diabetes mellitus $\cdot$ Anaemia $\cdot$

Risk factors $\cdot$ Clinical practice $\cdot$ Guideline targets $\cdot$ Epoetin

\begin{abstract}
Background: Type 2 diabetes is a leading cause of chronic kidney disease (CKD). The purpose of the Individual Risk-Profiling and Treatment in Diabetes Management (IRIDIEM) study was to evaluate the characteristics of CKD and associated comorbidities in patients with type 2 diabetes and CKD. Methods: IRIDIEM was conducted as a cross-sectional survey in 109 centres in 11 countries and included 1,205 patients aged $\geq 50$ years with type 2 diabetes for $\geq 5$ years and CKD stage 2-4. Results: $50 \%$ of patients were in CKD stage $4 ; 42 \%$ had CKD stage 3 , and $4 \%$ were in CKD stage 2 . Concomitant risk factors for cardiovascular disease and/or progression of CKD included hypertension ( $92 \%$ of patients), proteinuria (74\%), hypercholesterolaemia (65\%), and hypertriglyceridaemia (44\%). Only $64 \%$ of patients with hypertension had received antihypertensive medication. Anaemia was present in $34 \%$ of patients and increased markedly with advanced CKD stages. Of patients with documented anaemia, only $19 \%$ had received epoetin and only $7 \%$ had received iron
\end{abstract}

treatment. Conclusion: IRIDIEM documents the need to improve adherence to current best practice guidelines for management of cardiorenal risk factors including earlier initiation of antihypertensive treatment, lipid and anaemia management in this high-risk patient population.

Copyright $\odot 2010$ S. Karger AG, Basel

\section{Introduction}

The continuing rise in incidence of type 2 diabetes is predicted to lead to a doubling in cases from 171 million patients in 2000 to a projected 366 million patients by 2030 [1]. Type 2 diabetes is a leading cause of chronic kidney disease (CKD) [2] accounting for $44 \%$ of the primary causes of kidney failure [3] and is the most common primary comorbidity associated with end-stage renal disease $[4,5]$. Patients with type 2 diabetes and CKD also have a significantly elevated prevalence of cardiovascular disease (CVD) compared to non-diabetic patients $[6,7]$.

Anaemia is 2-3 times more common in patients with diabetes and CKD, is often more severe and is seen at earlier CKD stages compared to patients with non-diabetic renal disease $[8,9]$. The development of renal anaemia is

\section{KARGER}

Fax +4161306 1234 E-Mail karger@karger.ch www.karger.com
(C) 2010 S. Karger AG, Basel

$1420-4096 / 10 / 0332-0119 \$ 26.00 / 0$

Accessible online at:

www.karger.com/kbr
P. Stevens

Nephrology Department

Ethelbert Road, Canterbury CT1 6NG (UK)

Fax +44 122774095

E-Mail paul.stevens@ekht.nhs.uk 
Table 1. Inclusion and exclusion criteria

\begin{tabular}{|c|c|}
\hline$M a j$ & or inclusion criteria \\
\hline 1 & Male or female patient $\geq 50$ years of age \\
\hline 2 & $\begin{array}{l}\text { Confirmed diagnosis of type } 2 \text { diabetes at least } 5 \text { years prior } \\
\text { to enrolment according to WHO criteria }\end{array}$ \\
\hline 3 & Haemoglobin A1c $>6.5 \%$ \\
\hline 4 & CKD stages $2-4^{\mathrm{a}}$ \\
\hline 5 & $\begin{array}{l}\text { Proteinuria (confirmed by dipstick test or measured by } \\
\text { quantitative urine analysis) }\end{array}$ \\
\hline 6 & Written informed consent \\
\hline
\end{tabular}

Major exclusion criteria

1 Acute renal failure ${ }^{b}$

2 A GFR of $<15$ or $>90 \mathrm{ml} / \mathrm{min} / 1.73 \mathrm{~m}^{2}$

3 Dialysis

4 Non-diabetic nephrotic syndrome ${ }^{c}$

5 A presumed need for renal replacement therapy expected within 1 year after enrolment

6 Renal allograft transplantation

7 Anaemia due to other suspected non-renal causes (haemoglobin $<12 \mathrm{~g} / \mathrm{dl}$ due to ferritin, vitamin $\mathrm{B}_{12}$, or folate deficiencies, thyroid dysfunction, or anaemia) ${ }^{\mathrm{d}}$

8 Severe chronic heart failure $\mathrm{e}^{\mathrm{e}}$

9 Evidence of clinically relevant valvular heart disease

10 Acute or chronic infection or inflammatory process (CRP $>15 \mathrm{mg} / \mathrm{l})$

11 Clinically active malignant disease (except non-melanoma skin cancer requiring local treatment only) with a life expectancy $<1$ year

12 Severe hyperparathyroidism (intact parathyroid hormone $>800 \mathrm{pg} / \mathrm{ml}$ )

13 Haemoglobinopathies (e.g. sickle cell disease or thalassaemia of all types)

14 Current participation in another clinical trial or administration of another investigational product within the last 4 weeks prior to enrolment

a Cockcroft-Gault glomerular filtration rate $<90$ but $>15 \mathrm{ml} /$ $\min / 1.73 \mathrm{~m}^{2}$.

${ }^{\mathrm{b}}$ An acute deterioration of kidney function occurring over a period of hours or days.

${ }^{c}$ Nephrotic syndrome due to a cause other than diabetic nephropathy.

d According to WHO criteria for males and postmenopausal females.

${ }^{\mathrm{e}}$ New York Heart Association Class IV.

associated with a reduced quality of life and progression of the underlying disease [9-11]

Large population-based studies have suggested that early detection and treatment of anaemia, hyperglycaemia, hypertension and related diseases can slow the progression of diabetic nephropathy and reduce cardiovascular morbidity and mortality [12-14]. Early treatment of anaemia has also been suggested to delay onset and slow the progression of microvascular complications, including nephropathy [15]. Clinical practice guidelines have been developed to support the ongoing assessment and intervention to control type 2 diabetes and related comorbidities [16-20]. The optimal treatment strategy for patients with diabetes and CKD currently recommends strict control of blood pressure (BP) towards target values of $<130 / 80 \mathrm{~mm} \mathrm{Hg}$, treatment with angiotensin-converting enzyme inhibitors/angiotensin receptor blockers (ACEIs/ARBs) and control of blood glucose to $<130 \mathrm{mg} /$ $\mathrm{dl}(<7.22 \mathrm{mmol} / \mathrm{l})$ [21]. Based on the lack of clinically robust data, a recommendation for early initiation of anaemia treatment has not yet been included in the current best practice recommendations [16-20]. Treatment with erythropoiesis-stimulating agents (ESAs) is effective in correcting and maintaining haemoglobin $(\mathrm{Hb})$ levels in CKD patients with anaemia, but the optimal $\mathrm{Hb}$ target remains unclear and, although associated with an improved quality of life, $\mathrm{Hb}$ normalisation cannot be recommended [22-24]. On the other hand, ESAs may have greater utility in patients with type 2 diabetes than in non-diabetic patients with renal disease [25], as, in association with diabetic nephropathy, the kidney's erythropoietin production is reduced earlier in patients with diabetes [26].

Few studies have investigated the risk factors associated with the progression of diabetic nephropathy at CKD stages 3 or 4 [27-29] or in patients aged $\geq 50$ years [30].

The purpose of the Individual Risk-Profiling and Treatment in Diabetes Management (IRIDIEM) study was to document the characteristics of CKD and associated comorbidities in patients with type 2 diabetes and CKD [31]. Secondly, the study was designed to document compliance with best practice guidelines across Europe.

\section{Patients and Methods}

\section{Study Population}

The major inclusion and exclusion criteria are summarised in table 1. Informed consent was obtained from all participants. The study was conducted in accordance with the modified Declaration of Helsinki, and approved by the responsible ethical review committees, according to local requirements.

\section{Study Design}

IRIDIEM was designed as a European multicentre, observational, cross-sectional study. Patients were recruited through internists, general practitioners, diabetologists, endocrinologists, and nephrologists. After screening, patients fulfilling the inclu- 
Table 2. Study population demographics

\begin{tabular}{|c|c|}
\hline \multicolumn{2}{|l|}{ Characteristic } \\
\hline \multicolumn{2}{|l|}{ Age, years } \\
\hline Median (range) & $70(50-94)$ \\
\hline Male, $\%$ & 63 \\
\hline Caucasian, \% & 61 \\
\hline \multicolumn{2}{|l|}{ Body weight, kg } \\
\hline Median (range) & $82(45-151)$ \\
\hline \multicolumn{2}{|c|}{ Median (range) } \\
\hline \multicolumn{2}{|c|}{ Systolic blood pressure, $\mathrm{mm} \mathrm{Hg}$} \\
\hline Mean & 144 \\
\hline Median (range) & $140(80-211)$ \\
\hline \multicolumn{2}{|c|}{ Diastolic blood pressure, $\mathrm{mm} \mathrm{Hg}$} \\
\hline Mean & 79 \\
\hline Median (range) & $80(50-128)$ \\
\hline Active smoker, $\%$ & 34 \\
\hline \multicolumn{2}{|l|}{ Diabetes duration } \\
\hline$\leq 10$ years, $\%$ & $351(29 \%)$ \\
\hline$>10$ years, $\%$ & $847(71 \%)$ \\
\hline \multicolumn{2}{|l|}{ CKD stage } \\
\hline 2 & $52(4 \%)$ \\
\hline $3 a$ & $139(12 \%)$ \\
\hline $3 b$ & $355(30 \%)$ \\
\hline 4 & $604(50 \%)$ \\
\hline \multicolumn{2}{|c|}{$\begin{array}{l}\text { CKD stages are defined by the degree of reduction of kidney } \\
\text { function as follows: stage 2, minimally reduced (GFR } 60-89 \mathrm{ml} / \\
\min / 1.73 \mathrm{~m}^{2} \text { ); stage } 3 \mathrm{a} \text {, moderately reduced, (GFR } 45-59 \mathrm{ml} / \\
\min / 1.73 \mathrm{~m}^{2} \text { ); stage } 3 \mathrm{~b} \text {, moderately reduced, (GFR } 30-44 \mathrm{ml} / \\
\min / 1.73 \mathrm{~m}^{2} \text { ); stage } 4 \text {, severely reduced (GFR } 15-29 \mathrm{ml} / \mathrm{min} / \\
1.73 \mathrm{~m}^{2} \text { ). }\end{array}$} \\
\hline
\end{tabular}

sion/exclusion criteria (table 1) were entered directly into a central database via a web-based case record form by their enrolling physician. Baseline data, including current medical and lifestyle risk factors, were collected.

The objectives of IRIDIEM were to document the characteristics and sequelae of CKD and associated comorbidities (including anaemia, nephropathy and CVD) in patients with type 2 diabetes aged $\geq 50$ years. Secondary objectives were to evaluate the risk profiles for CKD and associated comorbidities, including their treatment.

\section{Risk Factor Assessments}

To assess CKD morbidity and associated comorbidities, the presence and status of potential risk factors for CKD progression were recorded. Along with the medical history of patients, information about the treating physicians' speciality was collected. Hypertension (standard definition: $>140 / 90 \mathrm{~mm} \mathrm{Hg}$ ) was assessed by defining cut-off points for systolic $(130 \mathrm{~mm} \mathrm{Hg})$ and diastolic $(80 \mathrm{~mm} \mathrm{Hg}) \mathrm{BP}$ in accordance with current guidelines for patients with high-risk factors [21,32-34]. The last three BP measurements were recorded and the lowest of these was used in
Table 3. Laboratory parameters

\begin{tabular}{|c|c|c|c|c|c|}
\hline \multirow[t]{2}{*}{ Variable } & \multirow[t]{2}{*}{$\mathrm{n}^{\mathrm{a}}$} & \multirow{2}{*}{$\begin{array}{l}\text { Me- } \\
\text { dian }\end{array}$} & \multicolumn{3}{|c|}{ Normal laboratory values } \\
\hline & & & female & & male \\
\hline $\mathrm{CRP}, \mathrm{mg} / \mathrm{l}$ & $693^{\mathrm{b}}$ & 5.0 & & $<6$ & \\
\hline HbA1c, \% & 1,144 & 7.4 & & $4.4-6.0$ & \\
\hline \multicolumn{6}{|c|}{ Fasting blood glucose, } \\
\hline $\mathrm{TC}, \mathrm{mg} / \mathrm{dl}$ & 1,078 & 187 & & $<240^{c}$ & \\
\hline $\mathrm{HDL}, \mathrm{mg} / \mathrm{dl}$ & 989 & 43 & $45-65$ & & $35-55$ \\
\hline $\mathrm{LDL}, \mathrm{mg} / \mathrm{dl}$ & 959 & 108 & & $<160$ & \\
\hline \multicolumn{6}{|l|}{ Albuminuria } \\
\hline $\mathrm{g} / 1$ & 227 & 0.1 & & $<0.02$ & \\
\hline g/day & 312 & 0.2 & & $<0.03$ & \\
\hline Proteinuria & & & & $0-8$ & \\
\hline $\mathrm{mg} / \mathrm{dl}$ & 654 & 0.6 & & $<0.15$ & \\
\hline g/day & 541 & 1.1 & & & \\
\hline Triglycerides, mg/dl & 1,064 & 159 & & $\leq 200$ & \\
\hline $\mathrm{Hb}, \mathrm{g} / \mathrm{dl}$ & 1,127 & 12.7 & $12-16$ & & $14-18$ \\
\hline Ferritin, ng/ml & 549 & 116 & $12-150$ & & $12-300$ \\
\hline TSAT, $\%$ & 358 & 22 & & $16-45$ & \\
\hline TIBC, $\mu \mathrm{g} / \mathrm{dl}$ & 268 & 319 & & $240-450$ & \\
\hline
\end{tabular}

${ }^{a}$ Number of patients with available data.

b 160 patients had CRP values $>15 \mathrm{mg} / \mathrm{l}$; considered a minor protocol violation.

${ }^{\mathrm{c}}$ For patients aged $>40$ years.

$\mathrm{CRP}=$ C-reactive protein; $\mathrm{TC}=$ total cholesterol.

analysis to minimise the effect of potential white coat hypertension. Hyperglycaemia was defined as content of HbAlc $>7.0 \%$ and fasting serum glucose $>130 \mathrm{mg} / \mathrm{dl}(>7.22 \mathrm{mmol} / \mathrm{l})$. Hypercholesterolemia was evaluated by measuring total cholesterol, low-density lipoprotein (LDL) and high-density lipoprotein (HDL) cholesterol. Hypercholesterolaemia was defined by LDL levels $>100$ $\mathrm{mg} / \mathrm{dl}(2.59 \mathrm{mmol} / \mathrm{l})$ or total cholesterol levels $>200 \mathrm{mg} / \mathrm{dl}(5.17$ $\mathrm{mmol} / \mathrm{l})$. Hypertriglyceridaemia was defined as blood level of triglycerides $>200 \mathrm{mg} / \mathrm{dl}(2.26 \mathrm{mmol} / \mathrm{l})$. With respect to assessing adherence to recommended indications for anaemia treatment, anaemia was defined as an $\mathrm{Hb}$ level $\leq 11 \mathrm{~g} / \mathrm{dl}$ following the recommendation of the US National Kidney Foundation [35], differing from WHO criteria: $\mathrm{Hb}<12 \mathrm{~g} / \mathrm{dl}$ in women and $\mathrm{Hb}<13 \mathrm{~g} / \mathrm{dl}$ in men [36]. In addition to standard laboratory testing including $\mathrm{Hb}$, haematocrit, CRP and recommended urine tests for proteinuria and albuminuria, laboratory parameters specifically associated with anaemia, i.e. assessment of iron status, were also evaluated: ferritin, transferrin saturation (TSAT) and total iron-binding capacity (TIBC).

\section{Statistical Analysis}

Data collected from the electronic Case Report Forms are presented as frequencies, or if appropriate, as medians with ranges. Comorbidities known to be risk factors for the progression of $\mathrm{CKD}$ were assessed by frequency distributions. Clinically relevant 
Table 4. Prevalence of risk factors by CKD stage

\begin{tabular}{lcccc}
\hline & CKD stage & & \\
\cline { 2 - 5 } & $2(\mathrm{n}=52)^{\mathrm{a}}$ & $3 \mathrm{a}(\mathrm{n}=139)^{\mathrm{a}}$ & $3 \mathrm{~b}(\mathrm{n}=355)^{\mathrm{a}}$ & $4(\mathrm{n}=604)^{\mathrm{a}}$ \\
\hline Hypertension, $\%$ & $30(58 \%)$ & $76(55 \%)$ & $197(55 \%)$ & $319(53 \%)$ \\
Proteinuria, $\%$ & $7(13 \%)$ & $22(16 \%)$ & $117(33 \%)$ & $271(45 \%)$ \\
Hypercholesterolaemia, $\%$ & & & & \\
$\quad$ High TC $(>200 \mathrm{mg} / \mathrm{dl})$ & $28(54 \%)$ & $57(41 \%)$ & $122(34 \%)$ & $202(33 \%)$ \\
$\quad$ Low HDL $(\leq 40 \mathrm{mg} / \mathrm{dl})$ & $9(17 \%)$ & $50(36 \%)$ & $111(31 \%)$ & $204(34 \%)$ \\
$\quad$ High LDL $(\geq 100 \mathrm{mg} / \mathrm{dl})$ & $31(60 \%)$ & $79(57 \%)$ & $171(48 \%)$ & $265(44 \%)$ \\
Hypertriglyceridaemia, $\%$ & $2(4 \%)$ & $105(76 \%)$ & $259(73 \%)$ & $440(73 \%)$ \\
Anaemiab, $\%$ & $4(3 \%)$ & $33(9 \%)$ & $136(23 \%)$ \\
\hline
\end{tabular}

TC $=$ Total cholesterol

${ }^{\mathrm{a}}$ Number of patients with available data. ${ }^{\mathrm{b}} \mathrm{Hb}<11 \mathrm{~g} / \mathrm{dl}$ (NKF 2000 criterion).

parameters (detailed in tables 3 and 4 ) on diabetes, CKD, iron status and anaemia were analysed by descriptive analyses and frequency distributions following standard methodology for analysis of continuous and categorical variables. Clinical management status (medication, diet, etc.) was also evaluated by frequency distributions summarised by CKD stage and comorbidity. Hierarchical cluster analyses were used to correlate patient characteristics, including comorbidities, with stage of CKD.

\section{Results}

\section{Demographics}

A total of 1,205 patients from 109 centres in 11 European countries (Austria, France, Germany, Greece, Ireland, Italy, Poland, Serbia and Montenegro, Slovenia, Sweden and the UK) were entered into the study database between 27 May 2004 and 30 August 2006. Of these, 7 patients were entered by error (patients had either type 1 diabetes or a confirmed diagnosis of diabetes type 2 for $<5$ years) and were therefore excluded from the primary analysis so that the presented data are based on a study population of 1,198 patients. Baseline characteristics are summarised in table 2. Median age was 70 years (interquartile range (IQR) 63.5-75.3) and 63\% of patients were male. The median duration of diagnosed diabetes was 15 years (IQR 10-22) and the median BMI was 29.4 (IQR 26.4-32.9); $15 \%$ of patients were morbidly obese (BMI $>35)$.

\section{Laboratory Parameters}

Relevant laboratory parameters are summarised in table 3 . The median estimated glomerular filtration rate
(GFR) was $29 \mathrm{ml} / \mathrm{min} / 1.73 \mathrm{~m}^{2}$ (IQR 19.9-40.3) and the median $\mathrm{Hb}$ level was $12.7 \mathrm{~g} / \mathrm{dl}$ (IQR 11.6-13.8). Median CRP level was $5 \mathrm{mg} / \mathrm{l}$ (IQR 2.6-15). As expected for this patient population, fasting blood glucose was elevated. Correspondingly, median HbAlc was also above the normal range, 7.4\% (IQR 6.8-8.4). Median values of lipids and triglycerides were within the normal range. Not surprisingly, albuminuria and proteinuria were above the normal values. Iron parameters such as serum ferritin, TSAT and TIBC had not been routinely assessed in all patients and thus were available only for 549 (46\%), 358 $(30 \%)$ and $268(22 \%)$ patients, respectively. Median values of iron indices were within the normal range.

Diabetic Nephropathy, CKD Stage and Age

Two thirds (66\%) of all patients had increased blood glucose level as evidenced by the high proportion of HbAlc (>7\%), and $17 \%$ had a fasting glucose level above the guideline glucose control target of $130 \mathrm{mg} / \mathrm{dl}(7.2$ $\mathrm{mmol} / \mathrm{l})$. Both these variables remained relatively stable across all CKD stages and all age groups (not shown). As expected, the degree of renal impairment progressed gradually with age (fig. 1a, b) and was more severe in patients with a duration of diabetes $>10$ years.

\section{Risk Factors for CKD Progression and Cardiovascular Disease}

Most patients had multiple risk factors for CKD progression and CVD (fig. 2). The most prevalent risk factors were uncontrolled hypertension (92\%) and proteinuria (74\%). Two thirds had been diagnosed with hypercholesterolaemia (65\%), approximately half with hypertriglyc- 


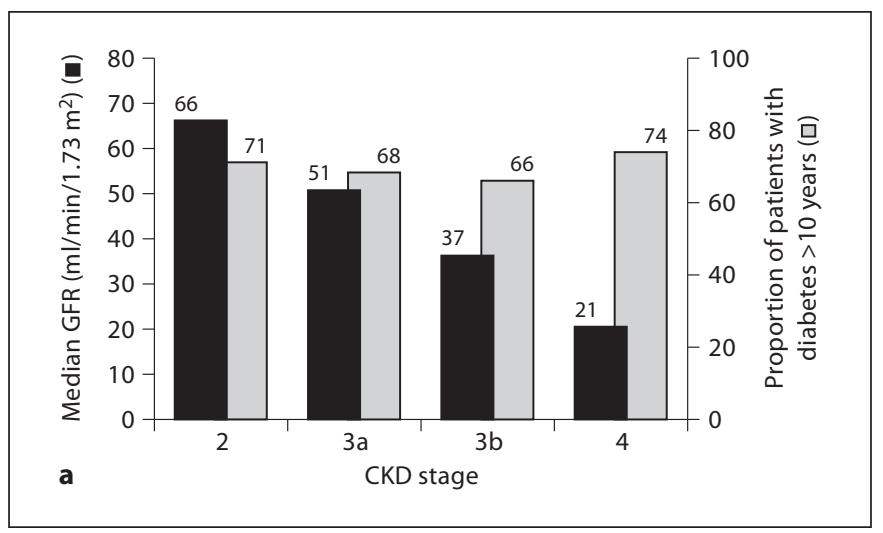

Fig. 1. Diabetic nephropathy, CKD stage and age. Median GFR values are shown together with the proportion of patients with

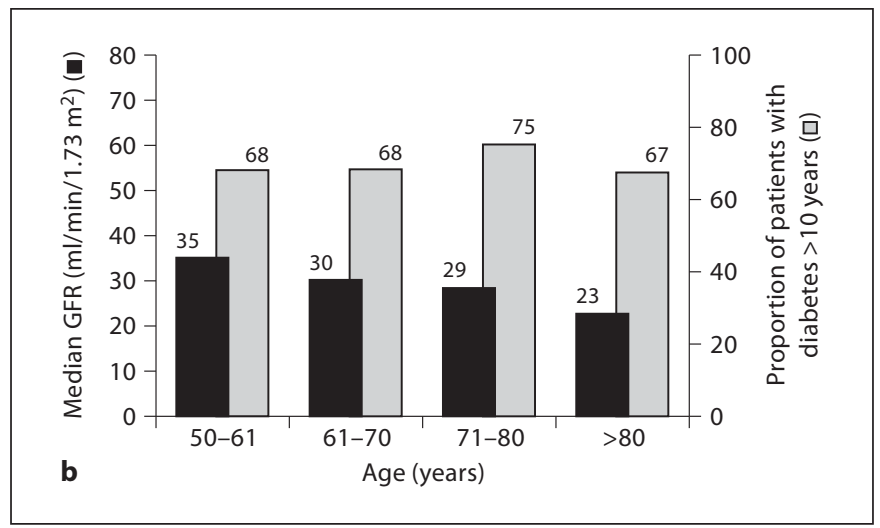

diabetes longer than 10 years. GFR was estimated by CockcroftGault. a Summary by CKD stage. b Summary by age groups.
Fig. 2. Risk factors for CKD by CKD stage. Proportion of patients with risk factors is shown by CKD stage (data from medical history).

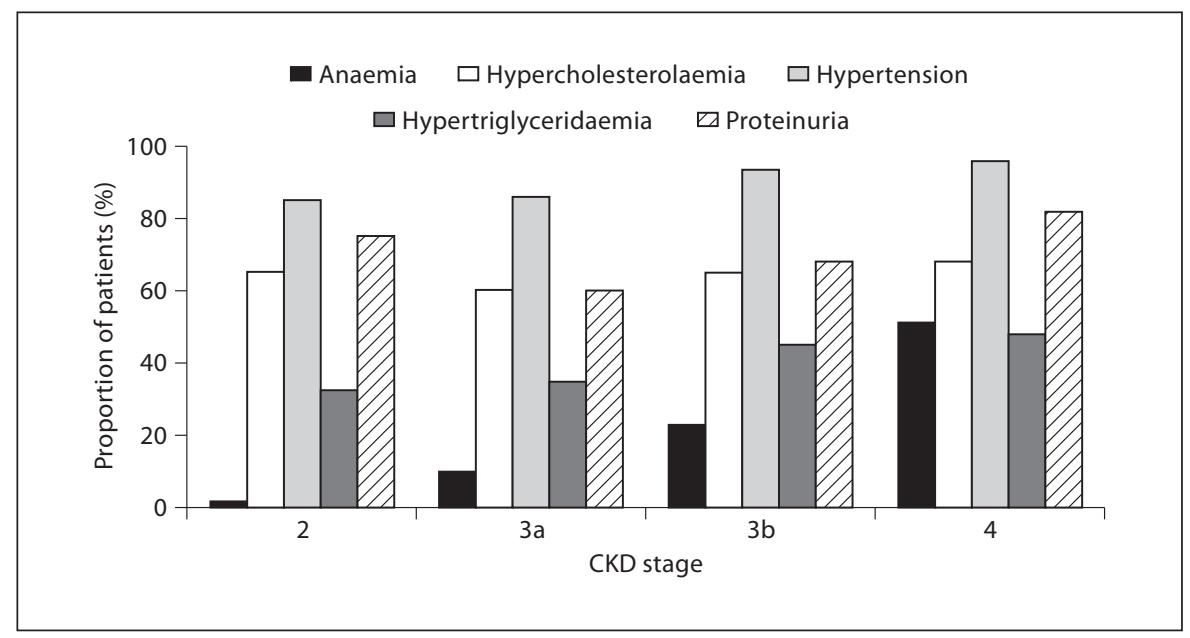

eridaemia (44\%) and one third with anaemia (34\%). The proportion of patients with anaemia, defined by WHO criteria $(\mathrm{Hb}<12 \mathrm{~g} / \mathrm{dl}$ in women and $\mathrm{Hb}<13 \mathrm{~g} / \mathrm{dl}$ in men) [36], increased dramatically with CKD stage up to $>50 \%$ of patients at CKD stage 4 .

Overall, there was a clear association between risk factors and CKD stage. Hypertension was the most frequent comorbidity and the proportion of patients with hypertension was similar at all CKD stages (table 4). In contrast, the prevalence of anaemia and proteinuria increased in more severe CKD stages. Proteinuria was confirmed quantitatively in 534 patients.

\section{Prevalence and Treatment of Hypertension}

Half the patients (53\%) had both systolic and diastolic hypertension, with systolic hypertension the more prevalent of the two ( 81 vs. $58 \%$; table 5). Despite the high proportion of patients with hypertension, only two thirds (64\%) were treated with antihypertensive medication (ACEI or ARBs).

\section{Lipid Profiles and Lipid-Lowering Treatment}

The proportion of patients with high total cholesterol decreased slightly with CKD stage, paralleled by a decrease in the proportion of patients with high LDL (table 4). In contrast, the proportion of patients with low HDL doubled from CKD stage 2 to 4 . In each of these 
Table 5. Treatment for risk factors for CKD

\begin{tabular}{|c|c|c|}
\hline Risk factor/treatment & $\begin{array}{l}\text { Diagnosed } \\
\text { (\% of all) }\end{array}$ & $\begin{array}{l}\text { Treated } \\
\text { (\% of diagnosed) }\end{array}$ \\
\hline \multicolumn{3}{|l|}{ Hypertension } \\
\hline Systolic hypertension & $972(81 \%)$ & $618(64 \%)$ \\
\hline Diastolic hypertension & $692(58 \%)$ & $454(66 \%)$ \\
\hline Systolic and diastolic & $637(53 \%)$ & $415(65 \%)$ \\
\hline \multicolumn{3}{|l|}{ Hypercholesterolaemia } \\
\hline $\mathrm{TC} \geq 200 \mathrm{mg} / \mathrm{dl}$ & $420(35 \%)$ & $201(48 \%)$ \\
\hline $\mathrm{TC}<200 \mathrm{mg} / \mathrm{dl}$ & $658(55 \%)$ & $398(60 \%)$ \\
\hline $\mathrm{LDL} \geq 100 \mathrm{mg} / \mathrm{dl}$ & $560(47 \%)$ & $280(50 \%)$ \\
\hline $\mathrm{LDL}<100 \mathrm{mg} / \mathrm{dl}$ & $399(33 \%)$ & $256(64 \%)$ \\
\hline $\mathrm{HDL} \geq 40 \mathrm{mg} / \mathrm{dl}$ & $604(50 \%)$ & $337(56 \%)$ \\
\hline $\mathrm{HDL}<40 \mathrm{mg} / \mathrm{dl}$ & $385(32 \%)$ & $212(55 \%)$ \\
\hline Anaemia & $\begin{array}{l}408(34 \%)^{\mathrm{a}} \\
178(15 \%)^{\mathrm{b}}\end{array}$ & \\
\hline EPO & & $76(19 \%)^{c}$ \\
\hline Iron & & $28(7 \%)^{\mathrm{c}}$ \\
\hline EPO or iron & & $91(22 \%)$ \\
\hline $\begin{array}{l}\mathrm{TC}=\text { Total cholesterol. } \\
{ }^{\mathrm{a}} \text { Patients diagnosed wi } \\
\mathrm{g} / \mathrm{dl} \text { in females and }<13 \mathrm{~g} / \mathrm{c} \\
\mathrm{b} \text { Patients with } \mathrm{Hb}<11 \\
{ }^{\mathrm{c}} \text { Percent of the numbe } \\
\text { prior to screening. }\end{array}$ & $\begin{array}{l}\text { naemia prio } \\
\text { males). } \\
\text { at screening } \\
\text { f patients dia }\end{array}$ & $\begin{array}{l}\text { creening }(\mathrm{Hb}<12 \\
\text { sed with anaemia }\end{array}$ \\
\hline
\end{tabular}

subgroups, approximately half of the patients had been treated with lipid-lowering medication (table 5).

\section{Prevalence and Treatment of Anaemia}

A total of $178(15 \%)$ patients were diagnosed with anaemia $(\mathrm{Hb}<11 \mathrm{~g} / \mathrm{dl})$, requiring further evaluation and treatment according to guideline recommendations [1620]. The frequency of anaemia rose from 4 to $23 \%$ with progression of CKD from stage 2 to 4 (table 4 ). Of $34 \%$ of patients known to be anaemic, only $19 \%$ had received an ESA and only 7\% had received iron treatment (table 5).

A summary of clinical characteristics, guideline targets and proportion of patients achieving target, as well as level of evidence supporting the target, is provided in table 6. No linear correlation was observed between $\mathrm{Hb}$ levels and estimated GFR (Pearson correlation coefficient, $-0.004 ; \mathrm{p}=0.899$ ) suggesting there might be no causative effect between anaemia and CKD.

\section{Other Comorbidities}

Overall, half of the patients had known CVD (674 patients, 56\%), which was classified into four different cat- egories: peripheral vascular disease, ischaemic heart disease, heart failure and other, not specified, CVD. The most frequent comorbid conditions were peripheral vascular disease (27\%), myocardial infarction (16\%), stroke (10\%) and chronic heart failure (7\%). An increase in CVD prevalence with more severe stages of CKD was observed specifically in the proportion of patients suffering from ischaemic heart disease $(6,10,19$, and $15 \%$ at CKD stages $2,3 \mathrm{a}, 3 \mathrm{~b}$ and 4 , respectively). Peripheral vascular disease and other CVD appeared marginally more prevalent in patients with anaemia than in patients with normal $\mathrm{Hb}$ levels. Thus, peripheral vascular disease was diagnosed in $25 \%(\mathrm{n}=44)$ patients with anaemia compared with $19 \%(\mathrm{n}=185)$ patients without anaemia. Only $27 \%(\mathrm{n}=$ 327) of the study population had been treated with antiplatelet drugs to reduce the risk for a potential cardiovascular event.

\section{Discussion}

The IRIDIEM study results confirm that management of patients aged $\geq 50$ years with type 2 diabetes and CKD is currently suboptimal across Europe. The study suggests that implementation of guideline recommendations and achievement of targets are areas requiring considerable attention, and that nephrologists are as culpable as other clinicians in our failure to practise what we preach.

The combination of type 2 diabetes and CKD is an important health problem for patients aged $\geq 50$ years. Diabetes in patients with CKD accelerates progression and increases cardiovascular risk and prevalence of anaemia, contributing to the generally poor outcomes for patients with this disease combination.

In this study, $16 \%$ of patients had $\mathrm{Hb}<11 \mathrm{~g} / \mathrm{dl}$ and $34 \%$ had been diagnosed with anaemia previously. These levels are similar to previously reported rates of anaemia in patients with diabetes, with and without CKD. Thomas et al. $[8,37]$ reported $7 \%$ of patients with diabetes having $\mathrm{Hb}<11 \mathrm{~g} / \mathrm{dl}$ and $23 \%$ diagnosed with anaemia according to WHO criteria in one study and $23 \%$ patients with anaemia in another study. De Nicola et al. [38] differentiated prevalence of anaemia in patients with diabetes and CKD by CKD stage: $16 \%$ of patients with CKD stage 3 and $32 \%$ of patients with stage 4 had anaemia.

\section{Prevalence of Risk Factors/Treatment Guideline Target Attainment}

The most common risk factor in this population was hypertension. Although $>80 \%$ of the patients were diag- 
Table 6. Clinical characteristics and guideline recommendations

\begin{tabular}{lccccc}
\hline Characteristic & Median & IQR & $\begin{array}{l}\text { Guideline target } \\
\text { (EBPG, ADA 2004) }\end{array}$ & $\begin{array}{l}\text { \% meeting } \\
\text { target }^{\mathrm{a}}\end{array}$ & Evidence level \\
\hline Haemoglobin, g/dl & 12.7 & $11.6-13.8$ & $>11$ & 72 & $\mathrm{~A}^{\mathrm{b}}$ \\
HbAlc, \% & 7.4 & $6.8-8.4$ & $<7$ & 29 & 31 \\
Systolic BP, mm Hg & 140 & $130-155$ & $<130$ & 69 & $\mathrm{~B}$ \\
Diastolic BP, mm Hg & 80 & $70-85$ & $<80$ & 11 & $\mathrm{~A}$ \\
TC, mg/dl & 221 & $187-680$ & $<135$ & 42 & $\mathrm{~B}$ \\
LDL, mg/dl & 108 & $84-137$ & $<100$ & 62 & $\mathrm{C}$ \\
HDL, mg/dl & 44 & $37-137$ & $>40$ & 46 & $\mathrm{C}$ \\
Triglycerides, mg/dl & 159 & $108-227$ & $<150$ & 46 \\
\hline
\end{tabular}

EBPG = European Best Practice Guidelines; ADA = American Diabetes Association; TC = total cholesterol.

${ }^{a}$ Proportion of patients achieving target calculated for total number of patients with valid measurements.

${ }^{b}$ Levels of evidence are defined as follows: $\mathrm{A}=$ evidence available from at least one randomized controlled trial, preferably from meta-analysis of several controlled trials; $\mathrm{B}=$ evidence from good but uncontrolled open studies; $\mathrm{C}=$ opinion of consensus groups.

nosed with hypertension, only $64-66 \%$ were treated with ACEIs/ARBs and 55\% received lipid-lowering therapy. This value is higher than the proportion of patients receiving ACEI therapy in the ORAMA study at baseline (44\%) [39] and comparable to the figure reported in the PAERI study (60\%) [40]. The higher proportion of patients treated for hypertension found in the ACORD study at baseline (>84\%) [23] is probably due to the fact that inclusion criteria required a documented stable BP for 3 months prior to study entry. Combined with the finding that ACEIs/ARBs also have potential renoprotective effects through inhibition of the renin-angiotensin system [41], these data reinforce the necessity for ACEI and/or ARB treatment in this high-risk population, as recommended by current guidelines [21].

Proteinuria was the second most common risk factor in this patient population. Although $74 \%$ of patients had a documented history of proteinuria, quantitative data on proteinuria and albuminuria have been collected only in approximately half of patients (table 3 ). Regular monitoring of proteinuria as an established risk marker for progression of renal disease should be certainly advocated as part of an improved management of CKD.

Use of antiplatelet agents is recommended in diabetic patients over the age of 40 who are at increased risk of CVD $[42,43]$, although the POPADAD study in diabetics with asymptomatic peripheral arterial disease showed no significant prevention of cardiac mortality with antiplatelet use [44]. Nevertheless, CKD is a risk factor for CVD, so the use of antiplatelet agents in IRIDIEM (27\%) was lower than might be expected and substantially lower than the Miller et al. [45] study in similar patients (diabetes, mean age 64 years).

The mean HbAlc in the IRIDIEM population was $7.4 \%$ and thus did not meet the guideline glucose control target intended to slow the progression of nephropathy ( $<7 \%$ HbA1c) [19]. However, the observed mean HbAlc level is clearly influenced by the inclusion criterion of an HbAlc $>6.5 \%$ which was defined for this study in order to include a cohort of patients with a well-established diagnosis of diabetes managed under the conditions of daily clinical practise in which guideline targets are known but not necessarily achieved. From this perspective, the findings of our study cohort represent a population of suboptimally managed type 2 diabetic patients in which glucose control should be improved in order to attain currently recommended HbAlc target values.

Frequency of anaemia increased steadily with progression of CKD; however, anaemia remains undertreated in this population: only 1 in 4 patients diagnosed with anaemia was receiving epoetin (EPO) or iron. This is markedly lower than in the ORAMA study where $95 \%$ of patients were receiving either EPO or iron therapy [39].

The level of reporting of iron parameters (serum ferritin, TSAT, TIBC; $22-46 \%$ of patients) is also suboptimal compared to results from previous European studies. Specifically, serum ferritin was evaluated for $87 \%$, and TIBC for $47 \%$ of patients in the DOPPS study [46]. In the ESAM 2003 study, serum ferritin data were available for $91 \%$ and TSAT data for $64 \%$ of patients [47]. In 
this respect, patient data capture and/or appropriate patient referrals can be improved substantially in clinical practice.

\section{Future Perspectives}

The need for an interdisciplinary approach to manage patients with diabetes and CKD has been proposed in the past, but what is of paramount importance is that those guideline recommendations that are strongly supported by the evidence base are implemented in this high-risk population. The most striking deficiency in management is achieved BP control but the relatively low use of anaemia treatment with EPO and/or iron supplementation suggests that interdisciplinary cooperation with regards to these patients also remains suboptimal. The STENO-2 study illustrated the potential benefits of target-driven, multifactorial treatment conducted by multidisciplinary teams [48]. The follow-up to this study of IRIDIEM I, IRIDIEM II, will provide longitudinal data to determine how physician choices and treatment evolve with disease progression over 12 months, and will describe the effects of a web-based interventional tool aiming to increase guideline adherence.

Several lines of evidence suggest that ESAs have favourable effects on CVD and CKD, partially due to their effects outside the haematopoietic system $[15,49,50]$. Thus, EPO has been suggested to inhibit apoptotic injury and inflammation in the heart, kidney, nervous system, eyes and blood vessels (reviewed by Silverberg et al. [15]). In particular, protection against ischaemic injury of the kidney has been demonstrated suggesting a role for EPO also in kidney recovery $[49,50]$. Recent clinical trial data in patients with CKD and diabetes sound a clear note of caution against normalisation of $\mathrm{Hb}$ in patients with anaemia but, as with previous trials, demonstrate improvement in quality of life measures in patients adequately treated [51].
The combination of comorbidities observed in patients with CKD and type 2 diabetes who met the inclusion/exclusion criteria as defined for this study shows that this population has distinct requirements for coordinated treatment. At the same time, it must be noted that the observed comorbidity and treatment patterns observed only represent a snapshot of the total population of type 2 diabetics in Europe and are therefore not generalisable, for example for patients in whom treatment targets for glucose control, hypertension and dyslipidaemia are strictly followed. At the same time, the data we report here suggest that there is much potential to improve patient outcomes and reinforce the imperative for physicians to follow evidence-based guidance in risk factor management.

\section{Conclusions}

The IRIDIEM study provides an important cross-sectional survey of morbidity, comorbidities and current clinical practice in patients with type 2 diabetes and $\mathrm{CKD}$, and provides a basis for identification of measures needed to improve management of this patient population. These measures include both more stringent adherence to guidelines and ensuring earlier initiation of antihypertensive treatment, lipid, blood glucose and anaemia management.

\section{Acknowledgements}

We gratefully acknowledge the collaboration and commitment of all local investigators and their staff. This study was supported by a grant from F. Hoffmann-La Roche.

\section{References}

1 Wild S, Roglic G, Green A, Sicree R, King H: Global prevalence of diabetes: estimates for the year 2000 and projections for 2030. Diabetes Care 2004;27:1047-1053.

$\checkmark 2$ Middleton RJ, Foley RN, Hegarty J, Cheung CM, McElduff P, Gibson JM, Kalra PA, O’Donoghue D, New JP: The unrecognized prevalence of chronic kidney disease in diabetes. Nephrol Dial Transplant 2006;21:8892.
3 US Renal Data System: USRDS 2007 Annual Data Report: Atlas of Chronic Kidney Disease and End-Stage Renal Disease in the United States. Bethesda, National Institute of Diabetes and Digestive and Kidney Diseases, National Institutes of Health, US Department of Health and Human Services, 2007.

\footnotetext{
4 New JP, Middleton RJ, Klebe B, Farmer CK, de Lusignan S, Stevens PE, O’Donoghue D: Assessing the prevalence, monitoring and management of chronic kidney disease in patients with diabetes compared with those without diabetes in general practice. Diabet Med 2007;24:364-369.

5 Ritz E, Rychlik I, Locatelli F, Halimi S: Endstage renal failure in type 2 diabetes: a medical catastrophe of worldwide dimensions. Am J Kidney Dis 1999;34:795-808.
} 
-6 Smith A, Karalliedde J, De Angelis L, Goldsmith D, Viberti G: Aortic pulse wave velocity and albuminuria in patients with type 2 diabetes. J Am Soc Nephrol 2005;16:10691075.

7 Nag S, Bilous R, Kelly W, Jones S, Roper N, Connolly V: All-cause and cardiovascular mortality in diabetic subjects increases significantly with reduced estimated glomerular filtration rate: 10 years' data from the South Tees Diabetes Mortality Study. Diabet Med 2007;24:10-17.

8 Thomas MC, MacIsaac RJ, Tsalamandris C, Power D, Jerums G: Unrecognized anemia in patients with diabetes: a cross-sectional survey. Diabetes Care 2003;26:1164-1169.

-9 Li Vecchi M, Fuiano G, Francesco M, Mancuso D, Faga T, Sponton A, Provenzano R, Andreucci M, Tozzo C: Prevalence and severity of anaemia in patients with type 2 diabetic nephropathy and different degrees of chronic renal insufficiency. Nephron Clin Pract 2007; 105:c62-c67.

10 McFarlane SI, Salifu MO, Makaryus J, Sowers JR: Anemia and cardiovascular disease in diabetic nephropathy. Curr Diab Rep 2006; 6:213-218.

-11 Stevens PE, O’Donoghue D, Lameire NR: Anaemia in patients with diabetes: unrecognised, undetected and untreated? Curr Med Res Opin 2003;19:395-401.

12 Cooper ME: Pathogenesis, prevention, and treatment of diabetic nephropathy. Lancet 1998;352:213-219.

13 UK Prospective Diabetes Study (UKPDS) Group: Intensive blood-glucose control with sulphonylureas or insulin compared with conventional treatment and risk of complications in patients with type 2 diabetes (UKPDS 33). Lancet 1998;352:837-853.

14 The Diabetes Control and Complications Trial Research Group: The effect of intensive treatment of diabetes on the development and progression of long-term complications in insulin-dependent diabetes mellitus. $\mathrm{N}$ Engl J Med 1993;329:977-986.

15 Silverberg DS, Wexler D, Iaina A, Steinbruch S, Wollman Y, Schwartz D: Anemia, chronic renal disease and congestive heart failure the cardiorenal anemia syndrome: the need for cooperation between cardiologists and nephrologists. Int Urol Nephrol 2006;38: 295-310.

-16 Locatelli F, Aljama P, Barany P, Canaud B, Carrera F, Eckardt KU, Horl WH, Macdougal IC, Macleod A, Wiecek A, Cameron S: Revised European Best Practice Guidelines for the management of anaemia in patients with chronic renal failure. Nephrol Dial Transplant 2004;19:1-47.

- 17 National Kidney Foundation: KDOQI Clinical Practice Guidelines and Clinical Practice Recommendations for Anemia in Chronic Kidney Disease. Am J Kidney Dis 2006;47: 11-145.
18 Task Force on Diabetes and Cardiovascular Diseases of the European Society of Cardiology (ESC) and of the European Association for the Study of Diabetes (EASD): Guidelines on diabetes, pre-diabetes and cardiovascular diseases: executive summary. Eur Heart J 2007;28:136.

19 NICE: Type 2 diabetes: the management of type 2 diabetes, London 2008. www.nice.org. uk/CG66 (accessed Dec 1, 2009).

20 Locatelli F, Covic A, Eckardt KU, Wiecek A, Vanholder R: Anaemia management in patients with chronic kidney disease: a position statement by the Anaemia Working Group of European Renal Best Practice. Nephrol Dial Transplant 2009;24:348-354.

21 KDOQI: K/DOQI Clinical Practice Guidelines on Hypertension and Antihypertensive Agents in Chronic Kidney Disease. Am J Kidney Dis 2004;43:S1-S290.

22 Drueke TB, Locatelli F, Clyne N, Eckardt KU, Macdougall IC, Tsakiris D, Burger HU, Scherhag A: Normalization of hemoglobin level in patients with chronic kidney disease and anemia. N Engl J Med 2006;355:20712084.

-23 RitzE, Laville M, Bilous RW, O’Donoghue D, Scherhag A, Burger U, de Alvaro F: Target level for hemoglobin correction in patients with diabetes and CKD: primary results of the Anemia Correction in Diabetes (ACORD) Study. Am J Kidney Dis 2007;49: 194-207.

24 Singh AK, Szczech L, Tang KL, Barnhart H, Sapp S, Wolfson M, Reddan D: Correction of anemia with epoetin alfa in chronic kidney disease. N Engl J Med 2006;355:2085-2098.

25 Khoshdel A, Carney S, Gillies A, Mourad A, Jones B, Nanra R, Trevillian P: Potential roles of erythropoietin in the management of anaemia and other complications diabetes. Diabetes Obes Metab 2008;10:1-9.

26 Thomas MC, Tsalamandris C, Macisaac R, Jerums G: Functional erythropoietin deficiency in patients with type 2 diabetes and anaemia. Diabet Med 2006;23:502-509.

27 Holland DC, Lam M: Predictors of hospitalization and death among pre-dialysis patients: a retrospective cohort study. Nephrol Dial Transplant 2000;15:650-658.

28 Hutchinson TA, Thomas DC, MacGibbon B: Predicting survival in adults with end-stage renal disease: an age equivalence index. Ann Intern Med 1982;96:417-423.

29 Strojek K, Grzeszczak W, Ritz E: Risk factors for development of diabetic nephropathy: a review. Nephrol Dial Transplant 1997; 12(suppl 2):24-26.

30 UK Prospective Diabetes Study (UKPDS): XI: Biochemical risk factors in type 2 diabetic patients at diagnosis compared with agematched normal subjects: Diabet Med 1994; 11:534-544.
31 Lameire N, Stevens P, Raptis S, Thomas S, Schernthaner G: Individualized risk management in diabetics: how to implement best practice guidelines - design and concept of the IRIDIEM studies. Kidney Blood Press Res 2004;27:127-133.

- 32 Chobanian AV, Bakris GL, Black HR, Cushman WC, Green LA, Izzo JL Jr, Jones DW, Materson BJ, Oparil S, Wright JT Jr, Roccella EJ: The Seventh Report of the Joint National Committee on Prevention, Detection, Evaluation, and Treatment of High Blood Pressure: the JNC 7 Report. JAMA 2003;289: 2560-2572.

- 33 Mancia G, De Backer G, Dominiczak A, Cifkova R, Fagard R, Germano G, Grassi G, Heagerty AM, Kjeldsen SE, Laurent S, Narkiewicz K, Ruilope L, et al; The task force for the management of arterial hypertension of the European Society of Hypertension, The task force for the management of arterial hypertension of the European Society of Cardiology: 2007 guidelines for the management of arterial hypertension: The Task Force for the Management of Arterial Hypertension of the European Society of Hypertension (ESH) and of the European Society of Cardiology (ESC). Eur Heart J 2007;28:1462-1536.

34 Whitworth JA: 2003 World Health Organization/International Society of Hypertension statement on management of hypertension. J Hypertens 2003;21:1983-1992.

-35 National Kidney Foundation: K/DOQI Clinical Practice Guidelines for Anemia of Chronic Kidney Disease. Am J Kidney Dis 2000;37:S182-S238.

- 36 Baker SJ, DeMaeyer EM: Nutritional anemia: its understanding and control with special reference to the work of the World Health Organization. Am J Clin Nutr 1979;32:368-417.

- 37 Thomas MC, Cooper ME, Tsalamandris C, Macisaac R, Jerums G: Anemia with impaired erythropoietin response in diabetic patients. Arch Intern Med 2005;165:466469.

38 De Nicola L, Minutolo R, Chiodini P, Zoccali C, Castellino P, Donadio C, Strippoli M, Casino F, Giannattasio M, Petrarulo F, Virgilio M, Laraia E, Di Iorio BR, Savica V, Conte G: Global approach to cardiovascular risk in chronic kidney disease: reality and opportunities for intervention. Kidney Int 2006; 69:538-545.

-39 Locatelli F, Covic A, Macdougall IC, Wiecek A: ORAMA: a study to investigate EBPG impact on renal anaemia - design and baseline data. J Nephrol 2008;21:592-603.

-40 Lorber D, Reddan D: Clinical characteristics of chronic kidney disease patients with and without diabetes: a subanalysis of the PAERI study. Clin Nephrol 2006;66:11-16.

41 Ruilope LM: Renin-angiotensin-aldosterone system blockade and renal protection: angiotensin-converting enzyme inhibitors or angiotensin II receptor blockers? Acta Diabetol 2005;42(suppl 1):S33-S41. 
-42 Patrono C, Bachmann F, Baigent C, Bode C, De Caterina R, Charbonnier B, Fitzgerald D, Hirsh J, Husted S, Kvasnicka J, Montalescot $\mathrm{G}$, et al: Expert consensus document on the use of antiplatelet agents. The task force on the use of antiplatelet agents in patients with atherosclerotic cardiovascular disease of the European Society of Cardiology. Eur Heart J 2004;25:166-181.

43 Graham I, Atar D, Borch-Johnsen K, Boysen G, Burell G, Cifkova R, Dallongeville J, De Backer G, Ebrahim S, Gjelsvik B, HerrmannLingen C, Hoes A, Humphries S, Knapton M, Perk J, Priori SG, Pyorala K, Reiner Z, Ruilope L: European guidelines on cardiovascular disease prevention in clinical practice: executive summary. Eur Heart J 2007; 28:2375-2414.

44 Belch J, MacCuish A, Campbell I, Cobbe S, Taylor R, Prescott R, Lee R, Bancroft J, MacEwan S, Shepherd J, Macfarlane P, Morris A, Jung R, Kelly C, Connacher A, Peden N, Jamieson A, Matthews D, Leese G, McKnight J, O'Brien I, Semple C, Petrie J, Gordon D, Pringle S, MacWalter R: The prevention of progression of arterial disease and diabetes (POPADAD) trial: factorial randomised placebo controlled trial of aspirin and antioxidants in patients with diabetes and asymptomatic peripheral arterial disease. BMJ 2008;337:a1840.
4 Miller SR, Littenberg B, MacLean CD: Prevalence of antiplatelet therapy in patients with diabetes. Cardiovasc Diabetol 2005;4:18.

46 Locatelli F, Pisoni RL, Combe C, Bommer J, Andreucci VE, Piera L, Greenwood R, Feldman HI, Port FK, Held PJ: Anaemia in haemodialysis patients of five European countries: association with morbidity and mortality in the Dialysis Outcomes and Practice Patterns Study (DOPPS). Nephrol Dial Transplant 2004;19:121-132.

47 Jacobs C, Frei D, Perkins AC: Results of the European Survey on Anaemia Management 2003 (ESAM 2003): current status of anaemia management in dialysis patients, factors affecting epoetin dosage and changes in anaemia management over the last 5 years. Nephrol Dial Transplant 2005;20:3-24.
48 Gaede P, Vedel P, Larsen N, Jensen GV, Parving $\mathrm{HH}$, Pedersen $\mathrm{O}$ : Multifactorial intervention and cardiovascular disease in patients with type 2 diabetes. N Engl J Med 2003;348:383-393.

49 Sharples EJ, Patel N, Brown P, Stewart K, Mota-Philipe H, Sheaff M, Kieswich J, Allen D, Harwood S, Raftery M, Thiemermann C, Yaqoob MM: Erythropoietin protects the kidney against the injury and dysfunction caused by ischemia-reperfusion. J Am Soc Nephrol 2004;15:2115-2124.

50 Vesey DA, Cheung C, Pat B, Endre Z, Gobe G, Johnson DW: Erythropoietin protects against ischaemic acute renal injury. Nephrol Dial Transplant 2004;19:348-355.

51 Pfeffer MA, Burdmann EA, Chen CY, Cooper ME, de ZD, Eckardt KU, Feyzi JM, Ivanovich P, Kewalramani R, Levey AS, Lewis EF, McGill JB, McMurray JJ, Parfrey P, Parving HH, Remuzzi G, Singh AK, Solomon SD, Toto R: A trial of darbepoetin alfa in type 2 diabetes and chronic kidney disease. N Engl J Med 2009;361:2019-2032. 